\title{
Legal Aspects of the Need to Create Dna Database for Military Personnel
}

\author{
Arthur I. Khabirov, Gulnara M. Khamitova
}

\begin{abstract}
The relevance of this problem is conditioned by the prevailing political situation in the world community. Both world and local wars almost always entail many deaths, there are the cases of mass burial of the dead. In such cases, dead can often be determined only by genomic identification. Indirect DNA diagnostics are being used now, but the use of direct methods is more economical and faster, which requires the creation of a genomic data-base of all people who will be on the battlefield.

In the armed forces of the Russian Federation, soldiers carry an aluminum token on their chest, on which in-formation about the name and blood type is stamped. This method was used back in World War II to determine the identity of a soldier at his death. Of course, this method is not particularly effective, since it is quite difficult to "identify" a person by such small fragments. In this case, the help of geneticists is needed. The 124th Central Medi-cal Identification Research Laboratory of the Ministry of Defense of the Russian Federation, located in Rostov-on-Don, which was engaged in the identification of people in the Chechen Republic, has extensive identification experience.

At first, during the first Chechen campaign, the names of 700 dead servicemen were identified thanks to special laboratory methods. Further, the number of identified persons was already about 3 thousand, and this was not due to the fact that the number of losses increased.

Research is still ongoing. And, despite the fact that geneticists did a great job to identify the dead, there are still inscriptions on the graves: "Unknown soldier." A number is put in the place of the name with the hope that someday it will still be possible to identify this fighter [1].
\end{abstract}

Keywords: DNA examination, identification of military men, unidentified soldiers, genomic registration, ge-nomic base, DNA base, DNA material, identification of people.

\section{INTRODUCTION}

Now the problem is urgent. Recently intensive fights were held in Donbass that it is often difficult to identify bodies. The Ukrainian authorities took special measures, and in this regard, the Coordination Center decided to create a unified database of genomic examinations there. The Ministry of the Interior will be responsible for this base. They promise that the DNA examination will be free for the families of all the dead military men [2].

In fact, the main difficulty in identification is not the complexity of the technology, but the fact that you always have to compare the genetic profiles of the deceased and his relatives. There may be discrepancies, and possibly the absence of the deceased family. These factors make personality determination very difficult and slow. Thus, there

Revised Manuscript Received on November 08, 2019.

* Correspondence Author

Arthur I. Khabirov, Kazan Federal University

Gulnara M. Khamitova, Kazan State Medical University is a need to create a genetic database for all citizens who are in combat zones [1].

Since 1997, suitable banks have also been created in Germany, Belgium and other European countries to identify a person's identity. In March 2016, in the UK, the National DNA Database contained almost 6 million genetic profiles of individuals and more than 500 thousand taken from crime scenes. In just two years, the number increased by 94,274 and 33,059 genomes, respectively. Detection of crimes has increased by $63.2 \%$. This achievement, which is one of the leading ones in the West, has confirmed that the method of DNA base use is very effective [3].

Genomic registration in the Russian legal system is not sufficiently developed and studied yet. The emergence of a regulatory framework for the existence of this institution became important - the Federal Law of the Russian Federation No. 242-FL "On State Genomic Registration in the Russian Federation" (December 3, 2008).

\section{METHODS}

The study is based on the method of current Russian legislation and law enforcement practice and existing European (world) standard analysis for the purpose of legal unification $[4,386]$. The methods of legal modeling and forecasting make it possible to determine the need to amend existing Russian regulations, as well as the need to adjust judicial practice [5]. Thanks to the use of modeling and forecasting methods, the consequences of making such changes and adjustments can be ascertained with a sufficient degree of certainty, and it is also revealed how, ultimately, Russian law enforcement practice will be close to existing European (world) standards [6, 421]. The sociological method allows the assessment of social problems from a legal position, from the perspective of a legislator and law enforcer $[7,651]$. The interpretation method complements the comparative legal analysis in the study, which allows you to understand and compare Russian and European (world) legal standards $[8,62]$. The use of various methods allowed us to formulate the main theoretical conclusions and make our own proposals on the studied sphere of public relations $[9,70 ; 10]$.

\section{RESULTS AND DISCUSSION}

It is interesting to know the position of Igor Kornienko, Doctor of Biological Sciences, Head of the Laboratory "Identification of Biological Origin Objects" at the Academy of Biology and Biotechnology, Southern Federal University, Head of the Department of Molecular Genetic Identification, Branch No. 2111 of the Main State Center for Forensics at the Russian Ministry of Defense. He trained in the United States: "The words "The war is not over until the last 
soldier is identified" are stretched in capital letters at their Central Laboratory of Forensic Medicine." Igor Kornienko says that the US view of the situation with the unidentified is fundamentally different from ours. They also have millions of unidentified personalities from the time of Vietnam and the Korean, World War II. There are real brigades looking for the remains of soldiers. These people work with documents and study small plots of land. "But the most important thing is that they have the DNA depository of absolutely all military personnel," notes the doctor of biological sciences.

According to Igor Kornienko, all DNA materials of 6 million people who serve in the United States Army are stored in special containers. Biological material (namely, blood) must be handed over in the repository by all those sent to serve in the army. And when a soldier leaves, he has the right to take everything. Private DNA material may not be used without permission from this person. When a soldier dies, the material is taken out and research is carried out with its biological material to identify the remains. Thus, they do not disturb the relatives, but give them only accurate information. This reduces the search time of a person and is very convenient for quick identification $[11,15,16]$.

The fact that employees who work with biological databases have information about the health, well-being of a certain citizen can be a real threat, because the consequence of these data disclosure will be a violation of the right to privacy. Experts who are aware of DNA typing technologies claim that privacy concerns are exaggerated in order to undermine people's confidence in this type of research. A. Melnikov, an employee of the Criminal Expertise Centre at the Ministry of Internal Affairs (CEC MIA), argues that the analysis works only with those reagents aimed at finding a person, and not at his appearance determination. The database may contain only information that can be used to achieve the goals that are expressly provisioned by the Law on Genomic Registration.

\section{CONCLUSIONS}

The experience of genomic database creation and operation, accumulated during foreign genomic registration existence, can help to improve the legislative base in Russia more quickly and solve the organization problem and methodological issues of identity recognition in a short period. The effectiveness of DNA information use in investigations makes more profitable the further financing of enlargement, development, and improvement of the federal database of genomic information that currently exists $[12,13,14]$.

Depending on how difficult it is, a study of a deceased soldier genome costs \$200 - \$500 for the Ministry of Defense. At the same time, costs can be reduced by 4-10 times if you organize a well-functioning system for the preparation and maintenance of biological DNA material [2].

Thus, in order to start organizing a DNA depository, it is necessary to amend the Federal Law of the Russian Federation No. 242-FL “On State Genomic Registration in the Russian Federation" (December 3, 2008).

Namely, we propose the article 7 "Obligatory state genome registration" to be supplemented with part three and set out as follows:

"one. Obligatory state genomic registration is subject to:

1) persons convicted and serving some sentence of imprisonment for the commission of grave or especially grave crimes, as well as all categories of crimes against sexual integrity and sexual freedom of a person;

2) unidentified persons whose biological material was seized during the course of investigative actions.

3) unidentified corpses are subject to mandatory state genomic registration.

4. The military personnel of the Ministry of Defense of the Russian Federation are subject to compulsory genomic registration."

We also propose the article 9 "The conduct of mandatory state genomic registration" of the aforementioned law to be supplemented with the subparagraph 4 and set out as follows: "1. Mandatory state genomic registration concerning:

1) the persons referred to in paragraph 1, Part 1, Article 7 of this Federal Law shall be carried out by institutions executing criminal sentences of imprisonment, together with the units of the internal affairs bodies of the Russian Federation, the competence of which includes the specified type of activity;

2 ) the persons referred to in clause 2, Part 1, Article 7 of this Federal Law shall be carried out by preliminary investigation bodies, inquiry bodies together with the units of the internal affairs bodies of the Russian Federation, the competence of which is the specified type of activity, and forensic medical institutions that are the part of the state healthcare system;

3) unidentified corpses is carried out by preliminary investigation bodies, inquiry bodies and the bodies authorized to carry out operational-search measures to search for missing persons, as well as to establish a person's identity by unidentified corpses, together with the units of the internal affairs bodies of the Russian Federation, whose competence includes the specified type of activity, and the forensic medical institutions that are the part of the state healthcare system.

4) military personnel are carried out by expert institutions of the Ministry of Defense of the Russian Federation.

2. The procedure for compulsory state genomic registration is determined by the Government of the Russian Federation."

\section{SUMMARY}

The proposed changes to the current legislation of the Russian Federation will improve the identification system of dead soldiers by making it much faster. We also assume that this will make a huge contribution to the economy of our country, since the presence of a DNA base will be several times cheaper than the currently used methods in order to search for dead soldiers. In connection with the tense global situation which the Russian Federation is currently facing, the problems concerning legal military personnel should be put in the first place.

\section{ACKNOWLEDGEMENTS}

The work is performed according to the Russian Government Program of Competitive Growth of Kazan Federal University. 


\section{REFERENCES}

1. Ruslan Kadrmatov. Under his own name // Independent newspaper [Electronic resource]. - URL: http://nvo.ng.ru/notes/2003-08-29/8_selfname.html (reference date: 5.03.18).

2. Olga Artemyeva, Vladimir Litvinov. This is the face of war // Gazeta.ru [Electronic resource]. URL: https://www.gazeta.ru/social/2014/09/23/6233273.shtml (reference date: $03 / 14 / 18)$.

3. Byazrova K.P., Tokmakov D.S. To the issue of genome registration use in the investigation of crimes // Actual problems of jurisprudence: a collection of articles based on the materials of the Vth international scientific-practical conference No. 5 (5). - Novosibirsk: SibAK, 2017. pp. 6-11. (reference date: 03/05/18).

4. Comparative Law. An Introduction to the Comparative Method of Legal Study and Research. By Gutteridge H. C., K.C., LL.D (Cambridge Studies in International and Comparative Law, Vol. I.) London: Cambridge University Press. The Cambridge Law Journal. 1947. - 9(3). - pp. 386-387.

5. Dale, William. Legislative Drafting: A New Approach: a Comparative Study of Methods in France, Germany, Sweden and the United Kingdom. - London: Butterworths, 1977. - 341 p.

6. Artur I. Khabirov, Gulnara M. Khamitova. On The Issue of the Place of a Loan Commitment in the System of the Russian Law of Obligations // The Journal of Social Sciences Research. -2018. - Special Issue - 5. pp. 421-424.

7. Siems, M., \& Mac Síthigh, D. Mapping legal research. The Cambridge Law Journal. - 2012. - 71(3). - pp. 651-676.

8. Davies, P. Rectification versus interpretation: the nature and scope of the equitable jurisdiction. - The Cambridge Law Journal. - 2016. 75(1). - pp. 62-85.

9. Khabirov Artur. On the issue of the consensual construction of a loan agreement // National Academy of Managerial Staff of Culture and Arts Herald. - 2018. - № 3. - pp. 70-73.

10. Khabirov A. I., Khamitova Gulnara M. Legal problems of vaccinal prevention // DILEMAS CONTEMPORANEOS-EDUCACION POLITICA Y VALORES. - 2018. - Vol.6, Is. - Art. №39.

11. Victoria Safronova. About a hundred years later, a mammoth will run in our zoo. // Russian planet [Electronic resource]. URL: https: //rusplt.ru/info/about-copy/ (reference date: 5.03.18).

12. A.A. Panova, A.F. Sokolov. Generic Genomic Registration: pro et contra. // Encyclopedia of forensics [Electronic resource]. - URL: http://www.proexpertizu.ru/general_questions/616/ (reference date: 5.03.18).

13. Muyambiri, B., \& Chabaefe, N. N. The Finance-Growth Nexus in Botswana: A Multivariate Causal Linkage. Dutch Journal of Finance and Management, 2(2), (2018). 03.

14. Martínez-Alcalá, C. I., Ramírez-Salvador, J. A., Rosales-Lagarde, A., \& Jiménez-Rodríguez, B. Assistance and Support of Primary Caregivers through an eService Platform. Journal of Information Systems Engineering \& Management, 3(1), (2018).09.

15. Koskenoja, M. Factors Supporting and Preventing Master Thesis Progress in Mathematics and Statistics - Connections to Topic and Supervisor Selection. International Electronic Journal of Mathematics Education, 14(1), (2019). 183-195. https://doi.org/10.29333/iejme/3986

16. Zhatkin, D. Russian literary-critical reception of Burns at turning of the XIX-XX centuries. Opción, 34(85-2), (2018). 277-300 